\title{
PERAN SIKAP MEMEDIASI PENGARUH ELECTRONIC WORD OF MOUTH TERHADAP KEPUTUSAN BERKUNJUNG
}

\author{
Dewa Gede Kresna Mahaputra ${ }^{1}$ \\ Putu Yudi Setiawan ${ }^{2}$ \\ ${ }^{1,2}$ Fakultas Ekonomi dan Bisnis Universitas Udayana (Unud), Bali, Indonesia \\ email: dedekresna@yahoo.com
}

\begin{abstract}
ABSTRAK
Keputusan berkunjung adalah keputusan yang diambil seseorang sebelum mengunjungi suatu tempat atau wilayah dengan mempertimbangkan beberapa faktor. Bagi perusahaan perlu memperhatikan faktor-faktor yang dapat mempengaruhi keputusan konsumen untuk berkunjung demi meningkatkan pendapatan bagi perusahaan. Tujuan penelitian ini adalah untuk mengetahui pengaruh electronic word of mouth dan sikap terhadap keputusan berkunjug. Penelitian dilakukan pada konsumen Eco Bike Coffee Kintamani. Ukuran sampel sebanyak 100 responden, dengan purposive sampling. Pengumpulan data melalui kuesioner. Teknik analisis data adalah PLS dan uji sobel. Berdasarkan hasil analisis ditemukan bahwa electronic word of mouth dan sikap berpengaruh positif dan signifikan terhadap keputusan berkunjung, secara langsung. Electronic word of mouth secara tidak langsung dapat mempengaruhi keputusan berkunjung melalui sikap sebagai variabel mediasi. Hasil penelitian, mengimplikasikan Eco Bike Coffee perlu meningkatkan kesesuaian informasi yang diperoleh untuk meningkatkan pengetahuan konsumen melalui forum di internet sehingga mampu diandalkan dan memberikan kesan yang lebih menyenangkan untuk menarik konsumen berkunjung.
\end{abstract}

Kata kunci : merek electronic word of mouth, sikap, keputusan berkunjung

\section{ABSTRACT}

Visiting decision is decision someone takes before visiting a place by considering several factors. Companies need to pay attention to factors that can influence consumers' decisions to visit to increase revenue purpose of this study to determine effect electronic word of mouth and attitudes towards visiting decisions. The research was conducted at Eco Bike Coffee Kintamani. 100 respondents were used with purposive sampling. Data collectedby questionnaires. PLS and sobel test were used. Based on results it was found that electronic word of mouth and attitude had positive and significant effect on visiting decisions, directly. Electronic word of mouth can indirectly influence visiting decisions through attitude as mediating variable. The results of the study, implying that Eco Bike Coffee needs to improve the suitability of information obtained to increase consumer knowledge through the internet so that they can be relied upon and give more pleasant impression to attract consumers to visit.

Keywords: brand electronic word of mouth, attitude, visiting decision 


\section{PENDAHULUAN}

Dewasa ini pengaruh globalisasi telah memberikan dampak terhadap masyarakat Indonesia yang saat ini memiliki tingkat konsumtif yang tinggi. Perilaku ini merupakan dampak dari arus Globalisasi yang masuk ke dalam budaya di Indonesia. Perilaku konsumtif pada umumnya disebabkan karena perilaku konsumen yang memanfaatkan nilai uang lebih besar dari nilai produksinya untuk barang dan jasa yang bukan merupakan kebutuhan pokok (Tambunan, 2007).

Hal tersebut jelas merangsang para pelaku bisnis untuk memperoleh laba sebanyak - banyaknya dengan memanfaatkan perilaku konsumtif masyarakat dewasa ini dengan menciptakan sebuah usaha atau bisnis. Dampak lainnya dari arus globalisasi ini adalah perkembangan pada teknologi yang kian hari semakin canggih. Hal ini tentu memberikan manfaat positif bagi para pelaku bisnis yang memanfaatkannya dalam bidang pemasaran untuk mencapai konsumen yang ditargetkan.(Pedersen et al., 2014)

Kemajuan teknologi yang semakin canggih dan inovatif ini diciptakan untuk membantu dan mempermudah pekerjaan manusia serta memberikan manfaat positif lainnya bagi kehidupan. Salah satu manfaat yang dapat dirasakan yaitu pada teknologi informasi, dimana pemanfaatan pada teknologi informasi ini mampu memudahkan penyebaran dan pencarian informasi secara tidak langsung melalui media internet.

Tabel 1.

Data Pengguna Internet di Indonesia

\begin{tabular}{cc}
\hline Tahun & $\begin{array}{c}\text { Jumlah Pengguna Internet } \\
\text { (Dalam Jutaan Orang) }\end{array}$ \\
\hline 2013 & 82 \\
2014 & 88,1 \\
2015 & 110,2 \\
2016 & 132,7 \\
2017 & 143,26 \\
\hline
\end{tabular}

Sumber : Asosiasi Penyelenggara Internet Indonesia, 2017

Berdasarkan data yang disajikan pada Tabel 1. dapat dilihat bahwa jumlah pengguna internet di Indonesia dari tahun ketahun mengalami peningkatan. Populasi penduduk Indonesia saat ini mencapai 262 juta orang. Menurut laporan yang disampaikan oleh Asosiasi Penyelenggara Jasa Internet Indonesia terdapat lebih dari 50 persen atau sekitar 143 juta orang telah terhubung jaringan internet sepanjang tahun 2017

The Nielsen Global Survey of E-commerce melakukan penelitian terhadap pergeseran perilaku belanja para generasi milenial. Penggolongan generasi $\mathrm{Y}$ atau milenial terbentuk bagi mereka yang lahir pada tahun 1980 - 1990, atau pada awal tahun 2000, dan seterusnya dimana perilaku generasi milenial ini lebih memilih jalur daring (online) untuk meneliti dan membeli beragam produk atau jasa dalam memenuhi kebutuhan sehari-hari (Goyette et al., 2010)

Internet menjadi salah satu wadah bagi para pelaku bisnis untuk mempromosikan bisnisnya, karena informasi yang tersebar di internet akan mudah diakses dan didapatkan oleh para pengguna internet secara luas. Manfaat - manfaat 
positif yang ditimbulkan dari pengaruh globalisasi ini jelas menjadi angin segar yang memberikan peluang bagi para pelaku bisnis untuk berlomba - lomba membangun sebuah bisnis untuk menghasilkan produk atau jasa yang sesuai dengan kebutuhan masyarakat. (Hennig et al. 2004).

Membangun sebuah usaha atau bisnsi bisa dilakukan dalam bentuk yang beraneka ragam. Salah satu bisnis yang saat ini sedang berkembang pesat di Indonesia adalah bisnis kafe. Berdasarkan data Asosiasi Pengusaha Kafe Restoran Indonesia (Apkrindo), pertumbuhan jumlah kafe dan restoran meningkat pada tahun 2012 yaitu sebesar $15-20 \%$ dan akan terus meningkat di kota - kota besar (Lim, 2013).

Menjamurnya bisnis kafe yang berkembang saat ini menuntut para pelaku bisnis untuk bertahan dan bersaing dengan pesaing lainnya. Inovasi dan kreatifitas menjadi salah satu indikator untuk sukses dalam bisnis. Beraneka ragam jenis olahan makanan dan minuman harus disesuaikan dengan trend yang berkembang saat ini dikalangan masyarakat untuk memenuhi harapan serta keinginan dari para konsumen. (Putra et al., 2018)

Munculnya bisnis kafe bermula dari kata minuman yang mirip dengan kata kafe, yaitu coffee atau kopi. Gagasan ini muncul dengan tujuan untuk memodernkan cara meminum sebuah kopi. Gagasan ini memang bukan berasal dari Indonesia, namun diadaptasi dari budaya luar untuk dipopulerkan di kalangan masyarakat luas. Gagasan ini berawal dari langkah bersejarah munculnya Starbucks di Indonesia, yang membuat masyarakat kemudian berpikir bahwa untuk meminum sebuah kopi pun bisa terlihat lebih berkelas (Lim, 2013).

Salah satu kafe yang saat ini sedang terkenal dikalangan masyarakat terutama bagi kaum muda di Bali adalah Eco Bike Coffee Kintamani. Hal ini terlihat dari rating yang dimiliki Eco Bike Coffee Kintamani pada website trip advisor dengan nilai 4,5 yang tergolong nilai yang tinggi dari total keseluruhan nilai yaitu 5 dan salah satu akun media sosialnya yaitu instagram yang telah memiliki jumlah followers sebanyak 2.644 akun.

Eco Bike Coffee Kintamani merupakan salah satu kedai dengan menggunakan konsep kafe yang menonjolkan hidangan kopinya. Eco Bike Coffee Kintamani mulai beroperasi sejak tahun 2017. Berdasarkan hasil wawancara yang dilakukan terhadap pemilik usaha ini, jumlah pengunjung yang datang masih belum sesuai target dimana intensitas pengunjung hanya ramai di hari tertentu saja.

Tingginya intensitas persaingan dengan jumlah pasar yang tinggi menuntut manajemen perusahaan untuk mampu mempertahankan konsumenya dengan konsep yang dimiliki oleh perusahaan. Meningkatkan intensitas kunjungan konsumen merupakan salah satu upaya yang dapat dilakukan Eco Bike Coffee Kintamani untuk meningkatkan dan mempertahankan eksistensi perusahaan.

Keputusan berkunjung dianalogikan sama dengan keputusan pembelian, seperti penelitian yang dilakukan oleh Jalilvand \& Samiei (2012) yang menyatakan bahwa keputusan berkunjung wisatawan sama dengan keputusan pembelian konsumen. Keputusan pembelian adalah proses pengintegrasian yang mengkombinasikan pengetahuan untuk mengevaluasi dua atau lebih perilaku alternatif dan memilih salah satu diantaranya (Peter \& Olson, 2000:162). Evaluasi dan perilaku konsumen sangat bergantung pada bagaimana konsumen menyikapi 
segala hal mengenai Eco Bike Coffee Kintamani dan salah satunya melalui faktor internal. Faktor internal adalah faktor psikologis yang berasal dari proses interen dalam diri seseorang dan sangat berpengaruh terhadap perilaku pembelian konsumen. Faktor psikologis konsumen mencakup persepsi, motivasi, pembelajaran, sikap dan kepribadian.(Gruen et al., 2006)

Son \& Bobby (2013) menjelaskan dalam teory of planned behavior, sikap terhadap perilaku didefinisikan sebagai perasaan positif atau negative individu tentang melakukan perilaku yang diinginkan. Menurut Robbins (2008:169) sikap adalah pernyataan - pernyataan atau penilaian evaluatif berkaitan dengan obyek, orang atau suatu peristiwa. Penilaian konsumen dapat dipengaruhi dari informasi yang didapatkan konsumen tersebut baik secara langsung maupun tidak langsung.

Berkembangnya teknologi informasi pada era globalisasi seperti saat ini, memungkinkan para konsumen untuk mendapatkan informasi dengan lebih mudah yang salah satunya melalui media electronic. Berkembangnya pemanfaatan media elektronik memungkinkan untuk konsumen memberikan penilaian terhadap suatu produk melalui media internet atau yang biasa disebut electronic word of mouth (Shahrinaz et al., 2016)

Menurut Syafaruddin \& Suharyono (2016), EWOM adalah suatu bentuk kesediaan konsumen untuk secara sukarela membagikan informasi kepada orang lain untuk membeli atau menggunakan produk suatu perusahaan melalui media internet.

Menurut Kamtarin (2012) penyebaran informasi melalui electronic word of mouth (EWOM) dilakukan melalui media online atau internet seperti melalui email, blog, chat room, facebook, twitter dan berbagai jenis media sosial lainnya yang bisa menimbulkan interaksi antara konsumen satu dengan konsumen lainnya.

Menurut Litvin et al. (2008) EWOM adalah bentuk dari komunikasi non formal yang diarahkan pada konsumen melalui sebuah teknologi berbasis internet terkait dengan karakteristik atau penggunaan barang dan jasa tertentu. Dengan adanya komunikasi sosial secara online ini akan secara otamatis bisa membantu konsumen berbagi pengalaman tentang produk atau jasa yang mereka peroleh dalam melakukan proses pembelian.

Berdasarkan hasil penelitian sebelumnya, peneliti melakukan pra-survey terlebih dahulu untuk mengetahui bagaimana respon responden terhadap variabel EWOM, sikap, dan keputusan berkunjung. Pra-survey dilakukan dengan menyebarkan kuesioner sementara, yang terdiri dari pertanyaan yang mewakili masing - masing variabel.

Kuesioner disebarkan kepada 15 konsumen potensial yang belum pernah berkunjung namun sudah pernah mengakses informasi melalui media sosial mengenai Eco Bike Coffee Kintamani di Kota Denpasar.

Berdasarkan Tabel 2. Hasil Kuesioner Pra-Survei yang terlebih dulu dilakukan, ditemukan hasil yang berbeda-beda. 13 orang dari responden mengatakan mendapatkan informasi yang diharapkan melalui media online mengenai Eco Bike Coffee Kintamani. 15 orang dari responden mengatakan Eco Bike Coffee Kintamani adalah salah satu café yang bagus. 12 responden memutuskan untuk mengunjungi Eco Bike Coffee Kintamani dalam waktu dekat. 
Tabel 2.

Hasil Kuesioner Pra-Survei

\begin{tabular}{clccc}
\hline \multirow{2}{*}{ No } & \multicolumn{1}{c}{ Pernyataaan } & \multicolumn{2}{c}{ Frekuensi Jawaban } & \multirow{2}{*}{$\begin{array}{c}\text { Jumlah } \\
\text { Responden }\end{array}$} \\
\cline { 3 - 4 } 1 & $\begin{array}{l}\text { Saya mendapatkan informasi yang } \\
\text { diharapkan melalui media online } \\
\text { mengenai Eco Bike Coffee Kintamani }\end{array}$ & 13 & 2 & 15 \\
$2 \begin{array}{l}\text { Eco Bike Coffee Kintamani adalah salah } \\
\text { satu café yang bagus }\end{array}$ & 15 & 0 & 15 \\
$\begin{array}{l}\text { Saya memutuskan untuk mengunjungi } \\
\text { Eco Bike Coffee Kintamani dalam } \\
\text { waktu dekat }\end{array}$ & 12 & 3 & 15 \\
\hline
\end{tabular}

Sumber : Hasil riset pendahuluan (2018)

Hasil pra-survei tersebut dapat disimpulkan bahwa rata-rata konsumen di Kota Denpasar menyatakan mereka mendapatkan informasi yang sesuai dan tertarik untuk berkunjung ke Eco Bike Coffee Kintamani, namun beberapa responden masih memiliki keluhan seperti pada informasi yang diberikan melalui media sosial belum memberikan manfaat yang maksimal sehingga perlu dilakukan penelitian lebih lanjut untuk memperbaiki kekurangan yang ada sehingga nantinya perusahaan dapat meningkatkan jumlah pengunjung.

Penelitian sebelumnya yang dilakukan oleh Widyanto et al. (2017), menyatakan bahwa EWOM berpengaruh signifikan terhadap keputusan berkunjung. Hasil lain ditemukan oleh Jalilvand et al. (2013) yang menyatakan bahwa EWOM berpengaruh signifikan terhadap sikap.

Hasil yang bertolak belakang ditemukan oleh Suwarduki et al. (2016) yang menyatakan bahwa EWOM berpengaruh tidak signifikan terhadap keputusan berkunjung dengan nilai koefisien jalur $(\beta)$ sebesar 0,179 dengan probabilitas sebesar $0,095(0,095>0,05)$, yang disebabkan oleh adanya faktor yang dapat mempengaruhi dalam pengambilan keputusan sehingga dapat mengubah minat berkunjung. Adhi et al. (2016) menyatakan dalam temuannya bahwa sikap berpengaruh signifikan terhadap keputusan berkunjung. Berdasarkan hasil yang dilakukan oleh peneliti sebelumnya, penelitian pengaruh EWOM terhadap keputusan berkunjung pada Eco Bike Coffee Kintamani menggunakan sikap sebagai variabel mediasi.

Berdasarkan rumusan masalah diatas, maka yang menjadi tujuan dari penelitian ini adalah sebagai berikut : 1) Untuk menjelaskan pengaruh EWOM terhadap keputusan berkunjung ke Eco Bike Coffee Kintamani. 2) Untuk menjelaskan pengaruh EWOM terhadap sikap mengenai Eco Bike Coffee Kintamani. 3) Untuk menjelaskan pengaruh sikap terhadap keputusan berkunjung ke Eco Bike Coffee Kintamani. 4) Untuk menjelaskan peran sikap memediasi pengaruh EWOM terhadap keputusan berkunjung ke Eco Bike Coffee Kintamani.

Penelitian ini tidak hanya memberikan manfaat yang dapat dirasakan oleh penulis saja, melainkan memberikan manfaat terhadap elemen atau pihak-pihak yang terkait dalam penelitian ini baik secara langsung maupun tidak langsung. Hasil penelitian ini nantinya diharapkan mampu memberikan kontribusi empiris tentang hubungan antara variabel electronic word of mouth, sikap, dan keputusan 
berkunjung konsumen ke Eco Bike Coffee Kintamani. Hasil penelitian ini diharapkan dapat menjadi referensi bagi perusahaan Eco Bike Coffee Kintamani dalam memanfaatkan aspek EWOM dan sikap sebagai strategi untuk meningkatkan keputusan berkunjung konsumen ke Eco Bike Coffee Kintamani.

Sari \& Pangestuti (2018) menyatakan bahwa EWOM berpengaruh signifikan terhadap keputusan berkunjung. Doosti et al. (2016) yang menyatakan bahwa EWOM berpengaruh signifikan terhadap sikap. Adhi et al. (2016) menyatakan bahwa sikap berpengaruh signifikan terhadap keputusan berkunjung. Themba \& Monica (2013) menunjukkan bahwa sikap konsumen mampu memediasi EWOM secara positif dan signifikan terhadap keputusan berkunjung. Dari pemaparan hasil studi empiris sebelumnya, maka kerangka konseptual dapat disusun seperti pada Gambar 1. sebagai berikut,

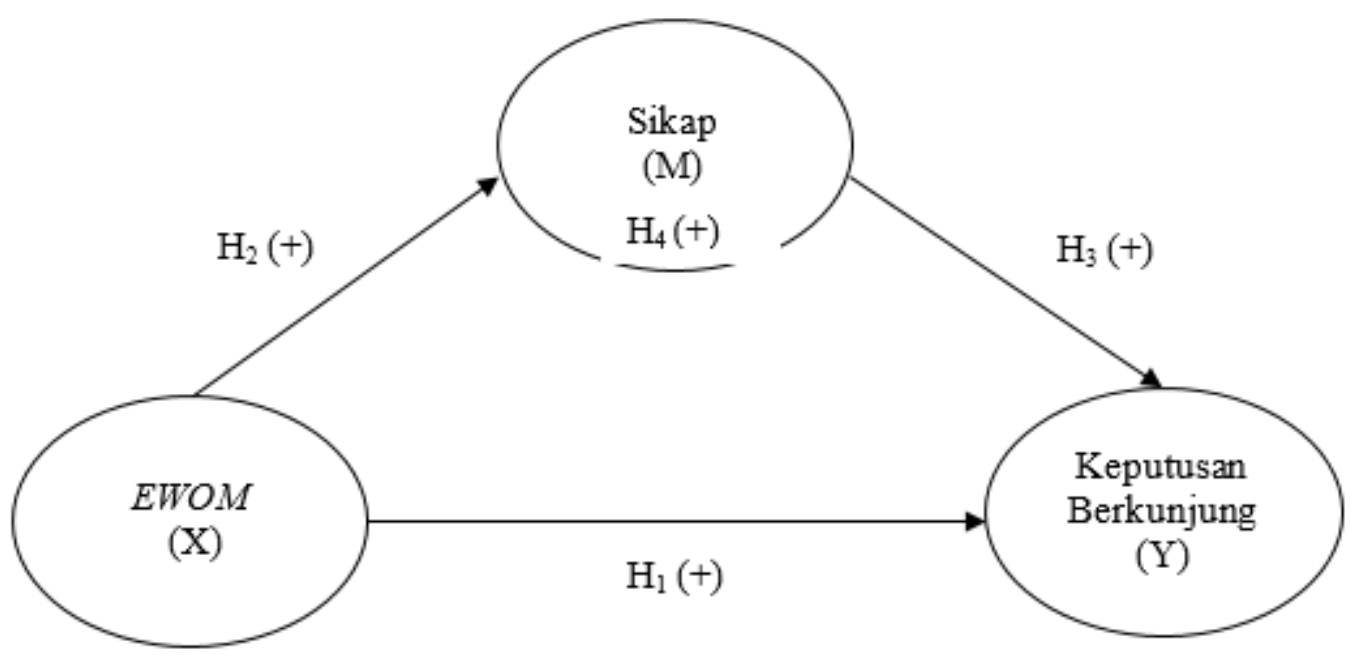

Gambar 1. Kerangka Konseptual Penelitian

Sari \& Pangestuti (2018) menyatakan bahwa EWOM berpengaruh positif dan signifikan terhadap keputusan berkunjung. Toruan \& Priansa (2018) menyatakan bahwa $E W O M$ berpengaruh positif dan signifikan terhadap keputusan berkunjung. Widyanto et al. (2017) menyatakan bahwa EWOM berpengaruh signifikan terhadap keputusan berkunjung. Berdasrkan kajian empiris sebelumnya, maka dapat disusun hipotesis sebagai berikut:

$\mathrm{H}_{1}$ : EWOM memiliki pengaruh positif dan signifikan terhadap keputusan berkunjung.

Doosti et al. (2016) yang menyatakan bahwa EWOM berpengaruh positif dan signifikan terhadap sikap. Penelitian dari Sinay \& Hussein (2015) menyatakan bahwa $E W O M$ berpengaruh positif dan signifikan terhadap sikap. Hasil yang sama juga ditemukan oleh Jalilvand et al. (2013) menyatakan bahwa EWOM berpengaruh positif dan signifikan terhadap sikap.Berdasarkan kajian empiris sebelumnya, maka dapat disusun hipotesis sebagai berikut:

$\mathrm{H}_{2}$ : EWOM memiliki pengaruh positif dan signifikan terhadap sikap. 
Adhi et al.(2016) menyatakan bahwa sikap berpengaruh signifikan terhadap keputusan berkunjung. Tompunu (2014) yang menyatakan bahwa sikap berpengaruh signifikan terhadap keputusan berkunjung. Hasil yang sama juga ditemukan oleh Saputra \& Semuel (2013) sikap konsumen berpengaruh positif dan signifikan terhadap keputusan berkunjung. Berdasarkan kajian empiris sebelumnya, maka dapat disusun hipotesis sebagai berikut:

$\mathrm{H}_{3}$ : Sikap memiliki pengaruh positif dan signifikan terhadap keputusan berkunjung.

Themba \& Monica (2013) menunjukkan bahwa sikap konsumen mampu memediasi $E W O M$ secara positif dan signifikan terhadap keputusan berkunjung. Syafaruddin \& Suharyono (2016) menyatakan hal yang sama bahwa EWOM terhadap keputusan berkunjung mampu dimediasi oleh sikap konsumen. EWOM memiliki pengaruh yang positif dan signifikan terhadap keputusan berkunjung melalui sikap sebagai mediasinya (Susilawati, 2017). Berdasarkan kajian empiris sebelumnya, maka dapat disusun hipotesis sebagai berikut:

$\mathrm{H}_{4}$ :Sikap mampu memediasi pengaruh EWOM terhadap keputusan berkunjung.

\section{METODE PENELITIAN}

Penelitian ini merupakan jenis penelitian yang menggunakan metode asosiatif dan kuantitatif. Penggunan metode asosiatif bertujuan untuk mengetahui sebab dan akibat dari variabel yang memengaruhi terhadap variabel yang dipengaruhi. Penelitian ini membahas tentang pengaruh EWOM terhadap keputusan berkunjung, pengaruh $E W O M$ terhadap sikap, pengaruh sikap terhadap keputusan berkunjung, serta peran sikap memediasi pengaruh EWOM terhadap keputusan berkunjung.

Penelitian ini dilakukan di Kota Denpasar sebagai ibukota dari Provinsi Bali. Kota Denpasar memiliki jumlah penduduk mencapai 897.300 jiwa yang menyebabkan mobilitas penduduk Kota Denpasar dapat dikatakan cukup tinggi (www.bps.bali.go.id). Rata - rata pengeluaran masyarakat kota juga menjadi salah satu alasan penentuan lokasi penelitian ini. Rata-rata pengeluaran per kapita per bulan penduduk Bali menurut kategori daerah tempat tinggal, baik di perkotaan maupun di perdesaan. Selama periode tahun 2015 - 2017, rata-rata pengeluaran per kapita per bulan penduduk di perkotaan lebih besar dibandingkan di perdesaan

Subjek dalam penelitian ini adalah konsumen potensial Eco Bike Coffee Kintamani. Sedangkan objek dalam penelitian ini adalah keputusan berkunjung konsumen yang muncul karena adanya pengaruh EWOM dan sikap pada Eco Bike Coffee Kintamani.

Variabel bebas adalah variabel yang menjadi sebab munculnya atau berubahnya suatu variabel terikat. Variabel bebas dalam penelitian ini merupakan EWOM yang disimbolkan dengan huruf (X).Variabel mediasi adalah variabel yang menghubungkan antara variabel bebas dan terikat. Variabel mediasi dalam penelitian ini adalah Sikap yang disimbolkan dengan huruf (M).Variabel terikat adalah variabel yang terpengaruh atau yang menjadi akibat karena adanya variabel bebas. Variabel terikat dalam penelitian ini adalah Keputusan berkunjung yang disimbolkan dengan huruf $(\mathrm{Y})$.

EWOM merupakan informasi yang diberikan secara online melalui media sosial yang dimiliki oleh Eco Bike Coffee Kintamani untuk konsumen secara luas. 
Terdapat 4 indikator yang diadopsi dari penelitian Setiawan \& Wibawa (2018) yang dapat digunakan dalam mengukur variabel EWOM antara lain : 1) Information $\left(\mathrm{X}_{1.1}\right)$. Information adalah sumber informasi online yang diberikan oleh Eco Bike Coffee Kintamani kepada konsumen secara luas. 2) Knowledge $\left(\mathrm{X}_{1.2}\right)$. Knowledge adalah kemampuan media sosial sebagai sumber informasi online dalam memberikan pengetahuan kepada konsumen mengenai Eco Bike Coffe Kintamani 3) Answer $\left(\mathrm{X}_{1.3}\right)$. Answer adalah kemampuan media sosial sebagai sumber informasi online dalam memberikan jawaban atas pertanyaan konsumen mengenai Eco Bike Coffee Kintamani.4) Reliability $\left(\mathrm{X}_{1.4}\right)$. Reliability adalah kesesuaian antara informasi yang didapatkan konsumen melalui media social secara online dengan kenyataan yang dapat diandalkan mengenai Eco Bike Coffee Kintamani.

Evaluasi konsumen melalui persepsi dan perasaan mereka terhadap suatu hal terhadap Eco Bike Coffee Kintamani. Terdapat 3 indikator yang diadopsi dari penelitian Zarrad \& Debab (2015) yang dapat digunakan dalam mengukur variabel sikap antara lain : 1) Tidak Bagus / Bagus $\left(\mathrm{M}_{2.1}\right)$. Konsumen merasa Eco Bike Coffee Kintamani adalah salah satu kafe yang bagus. 2) Tidak Bernilai / Bernilai $\left(\mathrm{M}_{2.2}\right)$. Konsumen merasa Eco Bike Coffee Kintamani adalah salah satu kafe yang memiliki nilai. 3) Tidak Menyenangkan / Menyenangkan ( $\left.\mathrm{M}_{2.3}\right)$. Konsumen merasa Eco Bike Coffee Kintamani adalah salah satu kafé yang menyenangkan.

Keputusan berkunjung merupakan proses pengambilan keputusan setelah mempertimbangkan beberapa faktor untuk berkunjung ke Eco Bike Coffee Kintamani. Menurut Wijaya \& Paramita (2014) terdapat 3 indikator yang dapat digunakan dalam mengukur variabel keputusan berkunjung antara lain : 1) Pengenalan kebutuhan $\left(\mathrm{Y}_{3.1}\right)$. Konsumen merasa bahwa Eco Bike Coffee Kintamani mampu memenuhi kebutuhan. 2) Penilaian (Y $\left.\mathrm{Y}_{3.2}\right)$. Konsumen lebih memilih Eco Bike Coffee Kintamani dibandingkan dengan kafe yang lain. 3) Keputusan Pembelian ( $\mathrm{Y}_{3.3}$ ). Konsumen memutuskan untuk melakukan pembelian ke Eco Bike Coffee Kintamani.

Dalam penelitian ini, data kuantitatifnya adalah usia responden, dan data jumlah penduduk di Bali berdasarkan gender.Data kualitatif pada penelitian ini adalah pendapat responden terhadap pernyataan yang meliputi electronic word of mouth, sikap, dan keputusan berkunjung.

Sumber primer adalah responden yang langsung memberikan tanggapan terhadap variabel - variabel penelitian yang tertera di kuesioner. Sumber sekunder dalam penelitian ini adalah sumber, berita - berita online, dan studi - studi empiris yang berkaitan dengan variabel yang terkait dalam penelitian ini.

Penelitian ini menggunakan alat pengumpulan data berupa kuesioner, sehingga dengan begitu perlu dilakukan pengujian validitas dan reliabilitas agar kuesioner tersebut layak untuk digunakan. Sugiyono (2014:389) menyatakan bahwa populasi adalah wilayah generalisasi yang terdiri atas obyek/subyek yang mempunyai kualitas dan karakteristik tertentu yang ditetapkan oleh peneliti untuk dipelajari kemudian ditarik kesimpulannya. Populasi dalam penelitian ini adalah masyarakat di Kota Denpasar yang belum pernah berkunjung ke Eco Bike Coffee yang tidak diketahui jumlah pastinya (Infinite).

Penelitian ini dianalisis dengan metode multivariate, maka jumlah anggota sampel minimal 5 - 10 dikali dari jumlah indikator yang akan diteliti (Sugiyono, 
2014:129). Jumlah indikator yang digunakan dalam penelitian ini berjumlah 10 sehingga jumlah sampel yang digunakan adalah $10 \mathrm{X} 10=100$ responden.

Metode Penentuan Sampel yang digunakan dalam penelitian ini yaitu non probability sampling. Teknik non probability sampling yang dipilih adalah purposive sampling yaitu teknik penentuan sampel dengan menggunakan pertimbangan atau kriteria tertentu. Kriteria penentuan sampel dalam penelitian ini adalah sebagai berikut 1) Jenjang pendidikan minimal SMA/SMK sederajat atau minimal 17 tahun. Pertimbangan ini digunakan dengan alasan seseorang dengan jenjang pendidikan minimal SMA atau sederajat diharapkan sudah dapat memahami dan mengerti isi dari kuesioner. 2) Belum pernah berkunjung ke Eco Bike Coffee Kintamani. 3) Sudah pernah mengakses informasi melalui internet mengenai Eco Bike Coffee Kintamani. 4) Berdomisili di Kota Denpasar.

\section{HASIL DAN PEMBAHASAN}

Eco Bike Coffee merupakan coffee shop yang menyajikan kopi khas Indonesia yang terletak di daerah Kintamani tepatnya di Jl. Raya Penelokan, Batur Selatan. Koleksi biji kopi berasal dari Kintamani Bali, Gayo Pantan Musara dan Batu Lonceng Jawa Barat serta Eco Bike Coffee memiliki beberapa varietas arabika.

Eco Bike Coffee memilih biji kopi khusus yang tumbuh subur di daerah Kintamani pada ketinggian 1000 m hingga 1500 m. Kintamani Arabica memiliki keunikan di Indonesia karena intensitas rasa yang ringan, keasaman sedang, dan karakter buah. Kopi yang dijual adalah $100 \%$ biji kopi Bali Kintamani Arabica berkualitas tinggi, yang diproses dengan hati-hati untuk mencapai kualitas terbaik yang sesuai dengan standar kualitas dan rasa yang tepat. Eco Bike Coffee hanya menggunakan biji kopi kualitas tinggi terbaik yang sesuai dengan standar tinggi untuk memaksimalkan kopi.

Selain kopi, Eco Bike Coffee juga menjual berbagai jenis makanan lain yaitu untuk main courses (Chinese foods, Balinese foods, Fried union, beef stroganol dan banyak lagi yang lainnya), untuk dessert (fried banana, fruit salad, tropical fruit, black rise pudding dan lain sebagainya), dan untuk minumnya Eco Bike Coffee juga menjual Hot Chocholate, Ginger, Juice dan banyak lagi aneka minuman yang dijual disana.

Eco Bike Coffee adalah Roaster profesional pertama di Kintamani yang melakukan roasting dan menyajikan kopi khas arabika. Visi yang dimiliki Eco Bike Coffee Kintamani yaitu mendidik petani kopi dari mengambil red bean hingga menjadi green bean, juga mengedukasi pelanggan bagaimana menikmati kopi dengan kopi gelombang ketiga.

Karakteristik responden penelitian merupakan profil dari 100 responden yang telah berpartisipasi dalam pengisian kuesioner penelitian ini. Profil responden memaparkan jenis kelamin, usia, pendidikan terakhir dan pekerjaan. Karakteristik responden, berdasarkan kriteria jenis kelamin, responden didominasi oleh laki-laki, dengan persentase sebesar 58 persen, sedangkan responden perempuan sebesar 42 persen. Karakteristik responden, berdasarkan kriteria usia responden berusia 18 21 tahun mendominasi dengan persentase sebesar 55 persen, sedangkan persentase terendah dimiliki oleh responden dengan rentang usia 30 - 33 tahun dengan presentase 5 persen. 
Karakteristik responden, berdasarkan kritria pendidikan terakhir responden, didominasi oleh responden dengan pendidikan akhir tingkat SMA / sederajat dengan persentase sebesar 60 persen, sedangkan persentase terendah dimiliki oleh responden dengan pendidikan akhir tingkat Pascasarjana sebesar 6 persen.

Karakteristik responden, berdasarkan kritria pekerjaan responden, didominasi oleh responden dengan pekerjaan pelajar / mahasiswa dengan persentase sebesar 68 persen, sedangkan persentase terendah dimiliki oleh responden dengan pekerjaan wiraswasta sebesar 8 persen.

Tabel 3.

Hasil Uji Validitas Instrumen Penelitian

\begin{tabular}{cclcc}
\hline Variabel & & \multicolumn{1}{c}{ Indikator } & $\begin{array}{c}\text { Pearson } \\
\text { Correlation }\end{array}$ & Keterangan \\
\hline EWOM & $\mathrm{X}_{1.1}$ & Information. & 0,861 & Valid \\
& $\mathrm{X}_{1.2}$ & Knowledge. & 0,664 & Valid \\
& $\mathrm{X}_{1.3}$ & Answer. & 0,776 & Valid \\
& $\mathrm{X}_{1.4}$ & Reliability. & 0,648 & Valid \\
Sikap & $\mathrm{M}_{1.1}$ & Bagus. & 0,881 & Valid \\
& $\mathrm{M}_{1.2}$ & Bernilai. & 0,850 & Valid \\
& $\mathrm{M}_{1.3}$ & Menyenangkan. & 0,739 & Valid \\
Keputusan & $\mathrm{Y}_{2.1}$ & Pengenalan Kebutuhan & 0,852 & Valid \\
Berkunjung & $\mathrm{Y}_{2.2}$ & Penilaian Konsumen & 0,685 & Valid \\
& $\mathrm{Y}_{2.3}$ & Keputusan Berkunjung & 0,720 & Valid \\
\hline Sumber: Data
\end{tabular}

Seluruh instrumen dalam penelitian memiliki angka Pearson Correlation yang lebih besar dari angka 0,30. Berdasarkan hasil tersebut dapat disimpulkan bahwa seluruh instrumen variabel dalam penelitian ini adalah valid sehingga dapat digunakan sebagai instrumen penelitian.

Tabel 4.

Hasil Uji Reliabilitas Instrumen Penelitian

\begin{tabular}{ccc}
\hline Variabel & Cronbach's Alpha & Keterangan \\
\hline EWOM & 0,721 & Reliabel \\
Sikap & 0,763 & Reliabel \\
Keputusan Berkunjung & 0,625 & Reliabel \\
\hline
\end{tabular}

Sumber: Data diolah, 2018

Seluruh Cronbach's Alpha menunjukkan nilai lebih dari 0,6. Hasil tersebut menunjukkan bahwa semua instrumen reliabel atau memiliki konsistensi atau kehandalan dalam mengukur variabel dalam penelitian ini, sehingga dapat digunakan untuk melakukan penelitian.

Variabel EWOM dalam penelitian ini merupakan variabel bebas $\left(\mathrm{X}_{1}\right)$, total pernyataan yang diukur dalam variabel ini yaitu sebanyak empat pernyataan, secara rinci hasil penelitian mengenai penilaian responden terhadap persepsi nilai disajikan pada Tabel 5 . 
Tabel 5.

Deskripsi Penilaian Responden Terhadap EWOM

\begin{tabular}{|c|c|c|c|c|c|c|c|c|}
\hline \multirow{2}{*}{\multicolumn{2}{|c|}{ Indikator }} & \multicolumn{5}{|c|}{ Skor Jawaban } & \multirow{2}{*}{$\begin{array}{l}\text { Rata- } \\
\text { rata }\end{array}$} & \multirow[b]{2}{*}{ Keterangan } \\
\hline & & STS & TS & $\mathbf{N}$ & S & SS & & \\
\hline $\mathrm{X}_{1.1}$ & Information & 0 & 0 & 3 & 48 & 43 & 4,34 & Sangat baik \\
\hline $\mathrm{X}_{1.2}$ & Knowledge & 0 & 0 & 34 & 49 & 17 & 3,83 & Baik \\
\hline $\mathrm{X}_{1.3}$ & Answer & 0 & 0 & 24 & 58 & 18 & 3,94 & Baik \\
\hline $\mathrm{X}_{1.4}$ & Reliability & 0 & 0 & 22 & 44 & 34 & 4,12 & Baik \\
\hline \multicolumn{7}{|c|}{ Rata-rata skor $E W O M$} & 4,06 & Baik \\
\hline
\end{tabular}

Sumber: Data diolah, 2018

Berdasarkan Tabel 5. pernyataan yang memiliki nilai rata-rata tertinggi adalah pernyataan $\mathrm{X}_{1.1}$ yaitu indikator information, yang mana dalam penelitian ini adalah pernyataan yang menyatakan bahwa forum di internet (media sosial) merupakan sumber informasi yang penting mengenai Eco Bike Coffee Kintamani sebagai tujuan wisata. Pernyataan ini masuk dalam kategori sangat tinggi karena berada di rentang interval 4,21 -5,00. Rata-rata terendah terdapat pada pernyataan $\mathrm{X}_{1.2}$ yang masuk dalam kategori tinggi karena berada di rentang interval 3,41 4,20. Secara keseluruhan variabel $E W O M$ masuk dalam kategori tinggi, hal ini dapat dilihat dengan menjumlahkan rata-rata setiap pernyataan kemudian dibagi dengan jumlah pernyataan dan memperoleh rata-rata skor EWOM sebesar 4,06 sehingga masuk dalam kategori tinggi karena berada di rentang interval 3,41-4,20. Hal ini berarti EWOM responden terhadap Eco Bike Coffee Kintamani adalah tinggi.

Variabel sikap dalam penelitian ini merupakan variabel mediasi $\left(\mathrm{M}_{1}\right)$. Total pernyataan yang diukur dalam variabel ini yaitu sebanyak tiga pernyataan.

Tabel 6.

Deskripsi Penilaian Responden Terhadap Variabel Sikap

\begin{tabular}{|c|c|c|c|c|c|c|c|c|}
\hline & \multicolumn{8}{|c|}{ Skor Jawaban } \\
\hline & Indikator & $\begin{array}{c}\text { STS } \\
(1)\end{array}$ & $\begin{array}{l}\text { TS } \\
\text { (2) }\end{array}$ & $\begin{array}{c}N \\
(3)\end{array}$ & $\begin{array}{c}S \\
(4)\end{array}$ & $\begin{array}{l}\text { SS } \\
\text { (5) }\end{array}$ & $\begin{array}{c}\text { Rata- } \\
\text { rata }\end{array}$ & Keterangan \\
\hline $\mathrm{M}_{1.1}$ & Bagus & 0 & 0 & 18 & 49 & 33 & 4,15 & Baik \\
\hline $\mathrm{M}_{1.2}$ & Bernilai & 0 & 0 & 24 & 51 & 25 & 4,01 & Baik \\
\hline $\mathrm{M}_{1.3}$ & Menyenangkan & 0 & 0 & 34 & 51 & 15 & 3,81 & Baik \\
\hline \multicolumn{7}{|c|}{ Rata-rata skor sikap } & 3,99 & Baik \\
\hline
\end{tabular}

Pernyataan yang memiliki nilai rata-rata tertinggi adalah pernyataan $\mathrm{M}_{1.1}$ yaitu indikator bagus, yang dalam penelitian ini adalah pernyataan yang menyatakan saya merasa Eco Bike Coffee Kintamani memiliki pemandangan yang indah. Pernyataan ini masuk dalam kategori tinggi karena berada di rentang interval 3,41 - 4,20. Rata-rata terendah terdapat pada pernyataan $\mathbf{M}_{1.3}$ yang masuk pula dalam kategori tinggi karena berada di rentang interval 3,41-4,20.

Secara keseluruhan variabel sikap masuk dalam kategori tinggi, hal ini dapat dilihat dengan menjumlahkan rata-rata setiap pernyataan kemudian dibagi dengan jumlah pernyataan dan memperoleh rata-rata skor pengalaman sebesar 3,99 
sehingga masuk dalam kategori tinggi karena berada di rentang interval 3,41-4,20. Hal ini berarti sikap responden terhadap Eco Bike Coffee Kintamani adalah tinggi/baik.

Variabel keputusan berkunjung dalam penelitian ini merupakan variabel terikat $\left(\mathrm{Y}_{1}\right)$. Total pernyataan yang diukur dalam variabel ini yaitu sebanyak tiga pernyataan.

Tabel 7.

Deskripsi Penilaian Responden Terhadap Variabel Keputusan Berkunjung

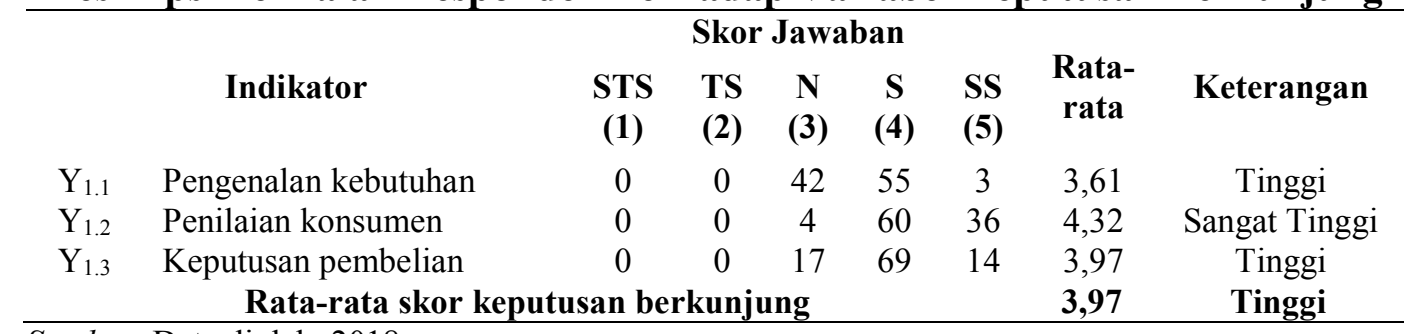

Sumber: Data diolah, 2018

Pernyataan yang memiliki nilai rata-rata tertinggi adalah pernyataan $\mathrm{Y}_{1.2}$ yaitu indikator penilaian konsumen, dimana dalam penelitian ini adalah pernyataan yang menyatakan konsumen lebih memilih Eco Bike Coffee Kintamani dibandingkan dengan café lainnya. Pernyataan ini masuk dalam kategori sangat tinggi karena berada di rentang interval 4,21 - 5,00. Rata-rata terendah terdapat pada pernyataan $\mathrm{Y}_{1.1}$ yang masuk pula dalam kategori tinggi karena berada di rentang interval 3,41-4,20.

Secara keseluruhan variabel keputusan berkunjung masuk dalam kategori tinggi, hal ini dapat dilihat dengan menjumlahkan rata-rata setiap pernyataan kemudian dibagi dengan jumlah pernyataan dan memperoleh rata-rata skor keputusan berkunjung sebesar 3,97 sehingga masuk dalam kategori tinggi karena berada di rentang interval 3,41-4,20. Hal ini berarti tingkat keputusan berkunjung konsumen terhadap Eco Bike Coffee Kintamani adalah tinggi.

Validitas model dibahas terlebih dahulu, sebelum membahas signifikansi pengaruh langsung masing-masing variabel eksogen terhadap variabel endogen dalam model penelitian. Terdapat tiga kriteria didalam penggunaan teknik analisis data dengan Smart PLS untuk menilai outer model menurut Putra et al. (2018) yaitu convergent validity, discriminant validity, serta average variance extracted (AVE). Outer model dinilai dengan cara melihat convergent validity (besarnya factor loading untuk masing-masing konstruk). Penelitian ini menggunakan batas minimal loading factor sebesar 0,5.

Berdasarkan hasil pengolahan, terlihat bahwa nilai outer model telah memenuhi kriteria convergent validity, semua indikator memiliki factor loading di atas 0,50 , sehingga dapat disimpulkan bahwa konstruk memiliki convergent validity yang baik.

Pada Tabel 8. Discriminant validity dari model pengukuran dengan reflektif indikator dinilai berdasarkan cross loading pengukuran dengan konstruk. Jika korelasi konstruk terhadap item pengukuran lebih besar dibandingkan dengan ukuran konstruk lainnya, maka hal ini menunjukkan bahwa konstruk laten 
memprediksi ukuran pada blok mereka lebih baik daripada ukuran pada blok lainnya.

Tabel 8.

Outer Loadings

\begin{tabular}{ccc}
\hline Variabel & Indikator & Factor Loading \\
\hline \multirow{3}{*}{ EWOM } & $\mathrm{X}_{1.1}$ & 0,772 \\
& $\mathrm{X}_{1.2}$ & 0,782 \\
& $\mathrm{X}_{1.3}$ & 0,788 \\
\multirow{2}{*}{ Sikap } & $\mathrm{X}_{1.4}$ & 0,709 \\
& $\mathrm{M}_{1.1}$ & 0,767 \\
& $\mathrm{M}_{1.2}$ & 0,868 \\
\multirow{3}{*}{ Keputusan Berkunjung } & $\mathrm{M}_{1.3}$ & 0,735 \\
& $\mathrm{Y}_{1.1}$ & 0,854 \\
& $\mathrm{Y}_{1.2}$ & 0,864 \\
& $\mathrm{Y}_{1.3}$ & 0,886 \\
\hline
\end{tabular}

Sumber: Data diolah, 2018

Tabel 9.

Cross Loadings

\begin{tabular}{cccc}
\hline & EWOM (X) & Keputusan Berkunjung (Y) & Sikap (M) \\
\hline M.1 & 0.375 & 0.485 & 0.767 \\
M.2 & 0.488 & 0.571 & 0.868 \\
M.3 & 0.410 & 0.525 & 0.735 \\
X.1 & 0.772 & 0.528 & 0.425 \\
X.2 & 0.782 & 0.450 & 0.417 \\
X.3 & 0.788 & 0.494 & 0.458 \\
X.4 & 0.709 & 0.512 & 0.341 \\
Y.1 & 0.488 & 0.854 & 0.506 \\
Y.2 & 0.555 & 0.864 & 0.510 \\
Y.3 & 0.633 & 0.886 & 0.693
\end{tabular}

Sumber: Data diolah, 2018

Data menjelaskan bahwa nilai cross loading menunjukkan adanya discriminant validity yang baik. Hal tersebut dapat dilihat dari nilai korelasi indikator terhadap konstruknya (loading factor) lebih tinggi dibandingkan nilai korelasi indikator tersebut dengan konstruk lainnya.

Model lain untuk menilai discriminate validity adalah membandingkan akar kuadrat dari average variance extracted (AVE) untuk setiap variabel dengan korelasi antar variabel dengan variabel lainnya didalam model. Model memiliki discrimint yang baik apabila kuadrat AVE untuk setiap variabel lebih besar daripada korelasi antar variabel dan variabel lain dalam satu model atau direkomendasikan nilai pengukuran AVE lebih besar dari 0,5. 
Tabel 10.

Hasil Uji Validitas Convergent AVE

\begin{tabular}{ll}
\hline & Rata-rata Varians Diekstrak (AVE) \\
\hline$E W O M(\mathrm{X} 1)$ & 0.583 \\
Keputusan Berkunjung (Y1) & 0.754 \\
Sikap (M1) & 0.628 \\
\hline
\end{tabular}

Sumber: Data diolah, 2018

Berdasarkan tabel di atas semua nilai AVE validitas confergent lebih besar dari 0,5. Dapat dinyatakan bahwa data dalam penelitian ini valid.

Composite reliability merupakan kelompok indikator yang mengukur sebuah variabel memiliki reliabilitas komposit yang baik, variabel dinyatakan reliabel jika nilai composite reliability $\geq 0,6$.

Tabel 11.

Hasil Uji Reliabilitas Cronbach's alpha

\begin{tabular}{ll}
\hline & Cronbach's Alpha \\
\hline EWOM (X1) & 0.761 \\
Keputusan Berkunjung (Y1) & 0.838 \\
Sikap (M1) & 0.700 \\
\hline
\end{tabular}

Sumber: Data diolah, 2018

Berdasarkan Tabel 11. dapat dilihat bahwa semua nilai Cronbach's alpha pada masing - masing variabel lebih besar dari 0,6. Dengan demikian dapat dinyatakan bahwa data dalam penelitian reliabel.

Tabel 12.

Hasil Uji Composite Reliability

\begin{tabular}{ll}
\hline & Composite Reliability \\
\hline EWOM (X1) & 0.848 \\
Keputusan Berkunjung (Y1) & 0.902 \\
Sikap (M1) & 0.834 \\
\hline
\end{tabular}

Sumber: Data diolah, 2018

Berdasarkan Tabel 12.dapat dilihat bahwa semua nilai Composite reliability pada masing - masing variabel lebih besar dari 0,6. Dengan demikian dapat dinyatakan bahwa data dalam penelitian reliabel.

Tabel 13.

Nilai R-squares

\begin{tabular}{cc}
\hline Variabel & R Square \\
\hline Keputusan Berkunjung & 0,564 \\
Sikap & 0,291
\end{tabular}

Sumber: Data diolah, 2018 
Data pada Tabel 13. menunjukkan bahwa nilai R-squares variabel keputusan berkunjung pada tabel sebesar 0,564, dapat diinterpretasikan bahwa 56,4 persen variabilitas konstruk keputusan berkunjung dijelaskan oleh variabel EWOM dan sikap, sedangkan 43,6 persen variabel keputusan berkunjung dijelaskan oleh variabel di luar model. Demikian pula nilai R-squares variabel sikap sebesar 0,291 dan dapat diinterpretasikan bahwa 29,1 persen variabilitas konstruk sikap dijelaskan oleh variabel $E W O M$, sedangkan 70,9 persen variabel sikap dijelaskan oleh variabel di luar model.

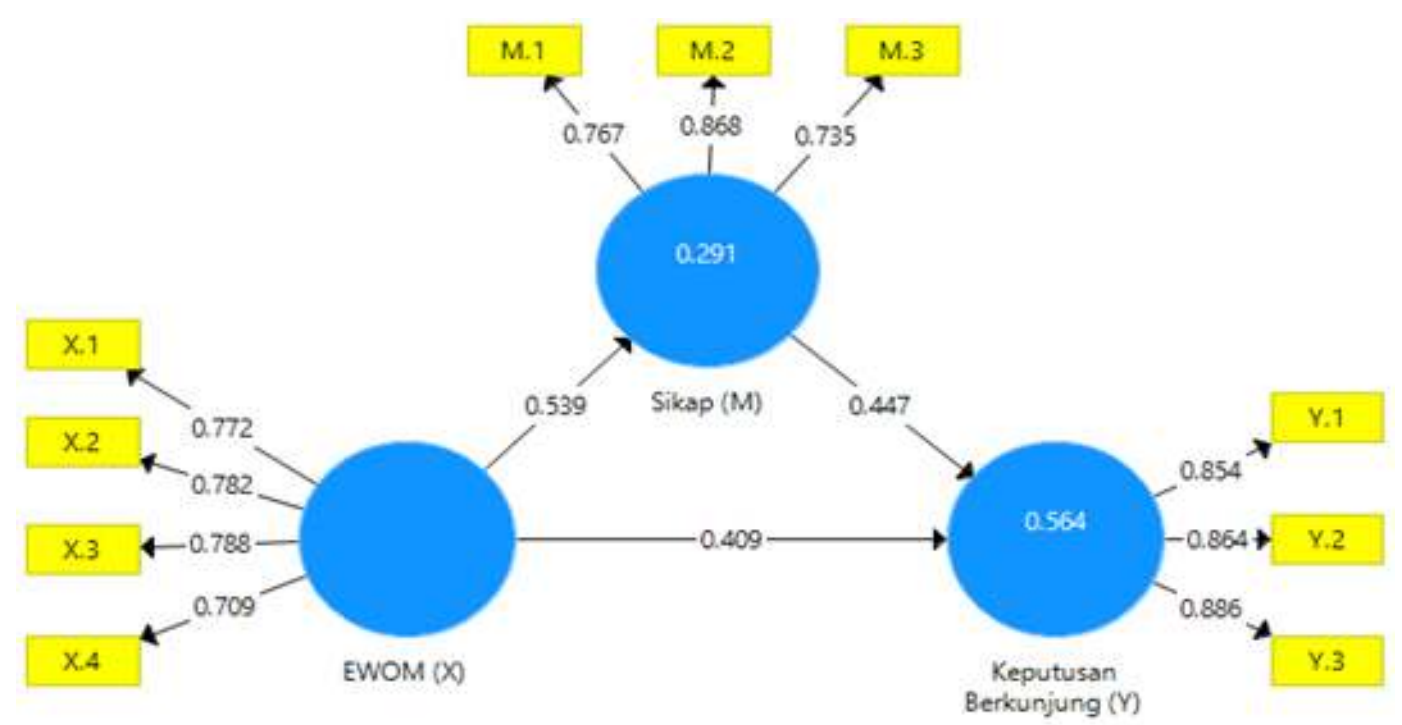

Gambar 2 Diagram Jalur Model Analisis

Sumber: data diolah, 2018

Model struktural diatas disebut sebagai model reflektif dimana covariance pengukuran indikator dipengaruhi oleh konstruk laten atau mencerminkan variasi dari konstruk unidimensional yang digambarkan dengan bentuk elips dengan beberapa anak panah dari konstruk ke indikator. Model ini menghipotesiskan bahwa perubahan pada konstruk laten akan mempengaruhi perubahan pada indikator.

Pengujian parameter yang diestimasi memberikan informasi yang sangat berguna mengenai hubungan antara variabel-variabel penelitian. Dasar yang digunakan dalam menguji hipotesis adalah nilai yang terdapat pada output path coefficients. Tabel 14. memberikan output estimasi untuk pengujian model struktural.

Penelitian ini sebelumnya telah ditentukan bahwa nilai t-tabel dengan signifikansi 5 persen atau 0,05. Semua koefisien jalur memiliki nilai t-statistik di atas 1,984 sehingga dinyatakan memiliki pengaruh yang signifikan.

Pengujian hipotesis pertama menunjukkan hasil bahwa hubungan antara EWOM terhadap keputusan berkunjung adalah signifikan dengan t-statistik sebesar 4,544 (>1,984). Nilai koefisien jalur sebesar 0,409 yang menunjukkan bahwa arah hubungan antara EWOM terhadap keputusan berkunjung adalah positif. Hipotesis 
$\mathrm{H}_{1}$ dalam penelitian ini menyatakan bahwa $E W O M$ memiliki pengaruh positif dan signifikan terhadap keputusan berkunjung dapat diterima.

Tabel 14.

Path Coefficient (Mean, STDEV, T-VALUES)

\begin{tabular}{lccccc}
\hline & $\begin{array}{c}\text { Original } \\
\text { Sample } \\
(\mathbf{O})\end{array}$ & $\begin{array}{c}\text { Sample } \\
\text { Mean } \\
(\mathbf{M})\end{array}$ & $\begin{array}{c}\text { Standard } \\
\text { Deviation } \\
(\text { STDEV) }\end{array}$ & $\begin{array}{c}\text { Standard } \\
\text { Error } \\
(\text { STERR) }\end{array}$ & $\begin{array}{c}\text { T Statistics } \\
(\mid \mathbf{O} / \text { STERR } \mid\end{array}$ \\
\hline EWOM -> & 0,409 & 0,412 & 0,090 & 0,090 & 4,544 \\
Keputuan & & & & & \\
Berkunjung & & & & & \\
EWOM -> Sikap & 0,539 & 0,551 & 0,073 & 0,073 & 7,384 \\
Sikap -> & 0,447 & 0,444 & 0,098 & 0,098 & 4,573 \\
$\begin{array}{l}\text { Keputusan } \\
\text { Berkunjung }\end{array}$ & & & & & \\
Sumber: Data diolah, 2018 & & & &
\end{tabular}

Pengujian hipotesis kedua menunjukkan hasil bahwa hubungan antara EWOM dengan sikap adalah signifikan dengan t-statistik sebesar 7,384 (>1,984). Nilai koefisien jalur sebesar 0,539 yang menunjukkan bahwa arah hubungan antara EWOM dengan sikap adalah positif. Hipotesis $\mathrm{H}_{2}$ dalam penelitian ini menyatakan bahwa EWOM memiliki pengaruh positif dan signifikan terhadap sikap dapat diterima.

Pengujian hipotesis ketiga menunjukkan hasil bahwa hubungan antara sikap dengan keputusan berkunjung adalah signifikan dengan t-statistik sebesar 4,573 $(>1,984)$. Nilai koefisien jalur sebesar 0,447 yang menunjukkan bahwa arah hubungan antara sikap dengan keputusan berkunjung adalah positif. Hipotesis $\mathrm{H}_{3}$ dalam penelitian ini menyatakan bahwa sikap memiliki pengaruh positif dan signifikan terhadap keputusan berkunjung dapat diterima.

Tabel 15.

Pengaruh Langsung, Pengaruh Tidak Langsung dan Pengaruh Total Variabel EWOM, Sikap, dan Keputusan Berkunjung

\begin{tabular}{|c|c|c|}
\hline Tipe Pengaruh & $\begin{array}{c}\text { Konstruk } \\
E W O M->\text { Keputusan Berkunjung }\end{array}$ & $\begin{array}{c}\text { Standardized } \\
\text { Estimates } \\
0,409\end{array}$ \\
\hline \multirow[t]{2}{*}{ Pengaruh Langsung } & $E W O M->$ Sikap & 0,539 \\
\hline & Sikap -> Keputusan Berkunjung & 0,447 \\
\hline $\begin{array}{l}\text { Pengaruh Tidak } \\
\text { Langsung }\end{array}$ & EWOM -> Sikap -> Keputusan Berkunjung & 0,241 \\
\hline Pengaruh total & EWOM $->$ Keputusan Berkunjung & 0,650 \\
\hline
\end{tabular}

Sumber: Lampiran 7 data diolah, 2018

Analisis ini ditujukan untuk mengetahui kekuatan pengaruh antar konstruk, baik pengaruh langsung, tidak langsung maupun pengaruh totalnya. Pengaruh langsung, pengaruh tidak langsung dan pengaruh total dari masing-masing variabel yang diteliti. 
Uji Sobel dilakukan untuk menguji signifikansi pengaruh tidak langsung variabel $E W O M\left(\mathrm{X}_{1}\right)$ terhadap variabel keputusan berkunjung $\left(\mathrm{Y}_{2}\right)$ melalui variabel sikap $\left(\mathrm{M}_{1}\right)$. Uji Sobel dihitung dengan menggunakan aplikasi Microsoft Excel 2007. Nilai koefisien z jika lebih besar dari 1,96, maka variabel sikap sebagai variabel mediasi dalam penelitian ini dinilai secara signifikan mampu memediasi pengaruh EWOM terhadap keputusan berkunjung. Peniliti melakukan uji Sobel untuk mengetahui signifikansi tidak langsung pengaruh variabel EWOM ( $\left.\mathrm{X}_{1}\right)$ terhadap variabel keputusan berkunjung $\left(\mathrm{Y}_{1}\right)$ melalui variabel sikap $\left(\mathrm{M}_{1}\right)$.

Hasil Uji Sobel telah dihitung menunjukkan bahwa nilai koefisien $\mathrm{z}$ adalah 3,8235 $>1,96$ dengan tingkat signifikansi $0,000<0,05$, sehingga $\mathrm{H}_{0}$ ditolak dan $\mathrm{H}_{1}$ diterima. Hasil tersebut mengartikan bahwa sikap sebagai variabel mediasi dinilai secara signifikan mampu memediasi pengaruh EWOM terhadap keputusan berkunjung.

Hasil estimasi model struktural menunjukkan bahwa pengujian terhadap hipotesis pertama menunjukkan signifikansi hubungan antara EWOM dan keputusan berkunjung dengan t-statistik sebesar 4,544 (>1,984). Nilai koefisien jalur sebesar 0,409 menunjukkan bahwa arah hubungan antara EWOM dengan keputusan berkunjung adalah positif, sehingga hipotesis $\mathrm{H}_{1}$ dalam penelitian ini yang menyatakan bahwa EWOM berpengaruh positif dan signifikan terhadap keputusan berkunjung dapat diterima. Hasil ini menjelaskan bahwa semakin baik informasi yang didapat melalui EWOM, semakin meningkatkan keputusan konsumen untuk berkunjung ke Eco Bike Coffee Kintamani.

Hasil ini sejalan dengan penelitian yang pernah dilakukan oleh Sari \& Pangestuti (2018) yang menyatakan pembeli atau pengunjung menentukan keputusannya dengan melihat beberapa item keputusan seperti berkunjung karena kepopuleran, keunikan wahana, dan banyaknya review yang mendukung yang didapat melalui media sosial. Hal inilah yang mendorong wisatawan untuk memutuskan berkunjung ke suatu tempat wisata. Toruan \& Priansa (2018) juga menyatakan bahwa tanggapan responden yang sangat baik melalui EWOM mampu meningkatkan keputusan berkunjung wisatawan. Hasil yang serupa juga ditemukan oleh Widyanto et al. (2017) yang menyatakan bahwa indikator EWOM yang terdiri dari kredibilitas, kualitas dan kuantitas EWOM berpengaruh terhadap keputusan berkunjung seseorang. Seseorang dapat mengetahui kondisi dari objek wisata seperti wahana, aksesbilitas dan sebagainya melalui informasi dan saran yang diterima di Instagram. Hal tersebut untuk menghindari adanya kesalahan dalam menentukan keputusan berkunjung ke suatu tempat wisata. Sehingga dapat disimpulkan bahwa peran $E W O M$ dalam menyediakan informasi mengenai suatu hal dapat menjadi kunci untuk meyakinkan konsumen dalam membuat keputusan berkunjung ke suatu tempat.

Hasil estimasi model struktural menunjukkan bahwa pengujian terhadap hipotesis kedua menunjukkan signifikansi hubungan antara EWOM dan sikap dengan t-statistik sebesar 7,384 (>1,984). Nilai koefisien jalur sebesar 0,539 menunjukkan bahwa arah hubungan antara EWOM dengan sikap adalah positif, sehingga hipotesis $\mathrm{H}_{2}$ dalam penelitian ini yang menyatakan bahwa EWOM berpengaruh positif dan signifikan terhadap sikap dapat diterima. Hasil ini 
menjelaskan bahwa semakin baik informasi yang didapat melalui $E W O M$, semakin baik sikap konsumen tentang Eco Bike Coffee Kintamani.

Hal ini sejalan dengan penelitian terdahulu yang pernah dilakukan oleh Doosti et al. (2016) yang menyatakan bahwa sebuah informasi mengenai pengalaman menyenangkan seorang wisatawan yang didapat melalui EWOM akan terus teringat dalam pikiran wisatawan, yang nantinya akan berkembang menjadi sebuah sikap positif bagi wisatawan tersebut. Penelitian dari Sinay \& Hussein (2015) juga menyatakan bahwa semakin baik informasi yang didapat melalui media online maka semakin baik pula sikap konsumen dalam menanggapi informasi tersebut. Hasil yang sama juga ditemukan oleh Jalilvand et al. (2013) menyatakan bahwa penggunaan website komunitas pariwisata menjadi wadah utama bagi para wisatawan untuk saling bertukar informasi secara online dengan wisatawan lainnya, yang nantinya dapat mempengaruhi sikap mereka terhadap suatu hal mengenai perasaan, pengalaman, pelayanan, dan lain sebagainya di dalam komunitas tersebut. Sehingga dapat disimpulkan bahwa EWOM berperan untuk membantu mempengaruhi sikap konsumen mengenai tanggapan positif atau negatif mengenai suatu hal untuk mempengaruhi tindakan yang akan diambil selanjutnya.

Hasil estimasi model struktural menunjukkan bahwa pengujian terhadap hipotesis ketiga menunjukkan signifikansi hubungan antara sikap dan keputusan berkunjung dengan t-statistik sebesar 4,573 (>1,984). Nilai koefisien jalur sebesar 0,447 menunjukkan bahwa arah hubungan antara sikap dengan keputusan berkunjung adalah positif, sehingga hipotesis $\mathrm{H}_{3}$ dalam penelitian ini yang menyatakan bahwa sikap berpengaruh positif dan signifikan terhadap keputusan berkunjung dapat diterima. Hasil ini menjelaskan bahwa semakin baik sikap konsumen terhadap Eco Bike Coffee Kintamani, semakin meningkatkan keputusan konsumen untuk berkunjung ke Eco Bike Coffee Kintamani.

Hal ini sejalan dengan penelitian terdahulu yang pernah dilakukan oleh Adhi et al. (2016) yang menyatakan bahwa setelah konsumen mendapatkan gambaran lengkap mengenai suatu tempat sebagai tujuan wisata, maka konsumen akan mulai menentukan apakah menyukai atau tidak menyukai produk yang ditawarkan. Sehingga memunculkan keyakinan dan perasaan yang baik akan mendorong pengunjung untuk cenderung memilih suatu tempat sebagai tempat tujuan wisata. Tompunu (2014) juga menyatakan sikap konsumen merupakan salah satu variabel penentu terhadap keputusan pembelian suatu produk. Semakin baik sikap konsumen terhadap suatu produk, maka semakin tinggi pula tingkat konsumen untuk memutuskan keinginannya terkait produk tersebut. Hasil yang sama juga ditemukan oleh Saputra \& Semuel (2013) yang menyatakan konsumen menganggap sikap menjadi faktor yang ikut menentukan keputusan terhadap suatu produk. Sehingga semakin baik sikap konsumen, maka semakin tinggi kesediaan konsumen untuk membeli suatu produk. Dapat disimpulkan bahwa sikap berperan penting dalam mempengaruhi dan meningkatkan keputusan konsumen untuk berkunjung ke suatu tempat destinasi wisata.

Peran Sikap memediasi pengaruh EWOM dengan keputusan berkunjung telah diuji dalam penelitian ini. Hasil uji Sobel yang telah dilakukan memperkuat hasil tersebut dengan nilai koefisien $\mathrm{z}$ yang diperoleh adalah 3,8235 $>1,96$, yang mengindikasikan bahwa sikap dinilai mampu memediasi pengaruh EWOM 
terhadap keputusan berkunjung ke Eco Bike Coffee. Sikap dapat dipengaruhi $E W O M$, selain itu sikap juga dapat mempengaruhi keputusan berkunjung dan disaat yang bersamaan penelitian ini juga menunjukkan bahwa EWOM secara langsung dapat mempengaruhi keputusan berkunjung. Sehingga dapat disimpulkan bahwa sikap dapat memediasi pengaruh EWOM terhadap keputusan berkunjung.

Hasil penelitian ini sejalan dengan penelitian terdahulu yang pernah dilakukan oleh Susilawati (2017) yang menyatakan bahwa salah satu penyebab dimensi EWOM yaitu positive self enhancement menjadi dimensi yang paling dominan karena sebagian besar ulasan wisatawan yang telah berkunjung mengungkapkan perasaan menyenangkan di media sosial. Sebagian besar pengunjung lainnya cenderung membuat keputusan berdasarkan respon sikap mereka terhadap ulasan positif yang ada di media sosial. Syafaruddin \& Suharyono (2016), menyatakan dari hasil temuannya bahwa EWOM akan semakin baik apabila dipengaruhi sikap konsumen untuk melanjutkan tindakannya dengan memutuskan pembelian secara online. Hasil yang serupa juga ditemukan oleh Themba \& Monica (2013) yang menunjukkan bahwa informasi yang ada di media sosial mampu mempengaruhi perilaku responden untuk lebih yakin dalam memutuskan melakukan pembelian online. Dapat disimpulkan dengan adanya EWOM dapat mempengaruhi sikap konsumen untuk memutuskan berkunjung ke Eco Bike Coffee Kintamani.

Berdasarkan hasil penelitian yang telah dilakukan menunjukkan bahwa penelitian ini mampu mengkonfirmasi beberapa penelitian terdahulu, sekaligus memperkuat penelitian terdahulu mengenai pengaruh EWOM, sikap, dan keputusan berkunjung. Hasil penelitian ini diharapkan digunakan sebagai masukan bagi Eco Bike Coffee Kintamani, sehingga dapat meningkatkan keputusan berkunjung dari konsumen dengan memperhatikan sikap sebagai fokus utamanya. Sebab, dari hasil yang diperoleh, sikap selain secara langsung dapat mempengaruhi secara positif terhadap terciptanya keputusan berkunjung, bisa dikatakan pula sebagai variabel yang dapat memediasi pengaruh EWOM terhadap keputusan berkunjung. Sesuai dengan hasil penelitian ini, indikator yang masih perlu ditingkatkan kembali adalah dengan meningkatkan kesesuaian informasi tentang Eco Bike Coffee Kintamani yang diperoleh oleh konsumen melalui forum di internet (media sosial) dan memberikan kesan yang lebih menyenangkan.

Hasil dari penelitian yang telah dilakukan, ditemukan bahwa masih ada beberapa keterbatasan dalam penelitian ini. Penelitian ini hanya sebatas meneliti mengenai pengaruh EWOM dan sikap terhadap keputusan berkunjung di Kota Denpasar, serta hasil penelitian ini tidak dapat digeneralisir maupun tidak dapat digunakan pada daerah lain maupun pada produk lain. Selain itu, penelitian ini hanya sebatas pada konsumen Eco Bike Coffee Kintamani di Kota Denpasar, dalam lingkup yang relatif kecil, dengan pengambilan data secara cross section sehingga dapat menimbulkan hasil yang berbeda jika terdapat penelitian serupa di waktu yang berbeda.

\section{SIMPULAN}

Berdasarkan tujuan penelitian, rumusan masalah dan hasil penelitian dengan pembahasan yang telah dipaparkan sebelumnya, maka dapat diambil kesimpulan 
bahwa EWOM berpangurh positif dan signifikan terhadap keputusan berkunjung konsumen ke Eco Bike Coffee Kintamani. Hasil ini menjelaskan bahwa semakin baik informasi yang didapat melalui EWOM, semakin meningkatkan keputusan konsumen untuk berkunjung ke Eco Bike Coffee Kintamani. EWOM berpengaruh positif dan signifikan terhadap sikap tentang Eco Bike Coffee Kintamani. Hasil ini menjelaskan bahwa semakin baik informasi yang didapat melalui $E W O M$, semakin baik sikap konsumen tentang Eco Bike Coffee Kintamani.

Sikap berpengaruh positif dan signifikan terhadap keputusan berkunjung ke Eco Bike Coffee Kintamani. Hasil ini menjelaskan bahwa semakin baik sikap konsumen terhadap Eco Bike Coffee Kintamani, semakin meningkatkan keputusan konsumen untuk berkunjung ke Eco Bike Coffee Kintamani. Sikap mampu memediasi $E W O M$ terhadap keputusan berkunjung. Hasil ini menjelaskan bahwa pengaruh $E W O M$ terhadap keputusan berkunjung akan lebih meningkat lagi bila EWOM juga mampu meningkatkan sikap positif terhadap Eco Bike Coffee Kintamani. Penulis memberikan saran berdasarkan hasil penelitian yang diharapkan dapat membantu Eco Bike Coffee Kintamani serta para peneliti selanjutnya yaitu : Deskripsi data hasil penelitian menunjukkan rata-rata yang baik, sehi ngga diharapkan perusahaan mampu mengelola kembali agar menjadi lebih baik kedepannya. Berdasarkan data yang diperoleh dari sejumlah 100 responden, terdapat dua indikator yang masih perlu ditingkatkan kembali. Hal ini terdapat pada indikator knowledge dan menyenangkan, dimana pada indikator knowledge konsumen merasa informasi yang diberikan melalui media sosial mengenai Eco Bike Coffee Kintamani sudah baik namun perlu ditingkatkan lagi manfaat dari informasi tersebut tentang kopi dan segala hal yang ada di Eco Bike Coffee Kintamani yang diperoleh oleh konsumen untuk menambah pengetahuan konsumen melalui media social yang dimiliki.

Pada indikator menyenangkan konsumen juga sudah memberikan respon yang baik, namun perlu ditekankan kembali oleh pihak Eco Bike Coffee Kintamani untuk lebih meningkatkan dan memperhatikan kesan menyenangkan yang didapat oleh konsumen sebelum dan sesudah berkunjung ke Eco Bike Coffee Kintamani agar menjadi lebih baik lagi, dengan cara selalu memperhatikan kualitas yang diberikan kepada konsumen, baik itu kualitas produk maupun kualitas pelayanan. Bagi peneliti selanjutnya, diharapkan agar dapat melakukan penelitian dengan cakupan yang lebih luas, dengan menambah variabel lain diluar penelitian ini. Selain itu, bagi peneliti selanjutnya diharapkan dapat melakukan penelitian dengan cakupan wilayah yang lebih luas.

\section{REFERENSI}

Adhi, I. A., Endang, M. G. W., \& Shanti, P. (2016). Pengaruh Faktor Psikologis terhadap Keputusan Berkunjung (Survei Pada Pengunjung Batu Zoo Jawa Timur Park 2). Jurnal Administrasi Bisnis, 30(1), 35-43.

Doosti, S., Jalilvand, M. R., Asadi, A., Khazaei Pool, J., \& Mehrani, P. (2016). Analyzing the influence of EWOM on visit intention: the mediating role of tourists' attitude and city image. International Journal of Tourism Cities, 2(2), 137-148. 
Goyette, I., Richard, L., Bergeron, J., \& Marticotte, F. (2010). E-WOM Scale Word-Of-Mouth Measurement Scale. Canadian Journal of Administrative Scienes, 27(1), 5-23.

Gruen, T. ., Osmonbekov, T., \& Czaplewski, A. . (2006). EWOM : The Impact of Customer-To-Customer Online Know-How Exchange On Customer Value and Loyalty. Journal of Business Research, 5(9), 449 - 456.

Hennig, T., Gwinner, K., Walsh, G., \& Gremler, D. (2004). EWOM Via ConsumerOpinion Platforms: What Motivates consumers to Articulate Themselves on The Internet? Journal of Interactive Marketing, 18(1), 38-52.

Jalilvand, M. ., Ebrahimi, A., \& Samiei, N. (2013). Electronic word of mouth effects on tourists' attitudes toward Islamic destinations and travel intention: an empirical study in Iran. Procedia - Social and Behavioral Sciences, 81(1), 484-489.

Jalilvand, \& Samiei. (2012). The impact of EWOM on a tourism destination choice: Testing the theory of planned behavior (TPB). Internet Research: Electronic Networking Applications and Policy, 2(2), 591-612.

Kamtarin, M. (2012). The Effect of Elec-tronic Word of Mouth, Trust and Perceived Value on Behavioral Intention from the Perspective of Consumers. International Journal of Academic Research in Economics and Management Sciences, 1(4), 1-7.

Lim, A. (2013). Trend Bisnis Café. Retrieved September 18, 2018, from http://www.arthinkle.com/articles/detail/trend-bisnis-cafe

Litvin, S. W., Goldsmith, R. E., \& Pan, B. (2008). Electronic Word-Of-Mouth In Hospitality And Tourism Management. Tourism Management, 29(3), 458468.

Pedersen, S. ., Razmerita, L., \& Colleoni, E. (2014). Electronic Word-of-Mouth Communication and Consumer Behaviour-An Exploratory Study of Danish Social Media Communication Influence. Journal- Language for Special Purposes, Professional Communication, Knowledge Management and Cognition, 5(1), 112-131.

Peter, J. P., \& Olson, J. C. (2000). Consumer Behavior Perilaku Konsumen dan Strategi Pemasaran (Edisi Keem). Jakarta: Erlangga.

Putra, I. K. S. W., Setiawan, P. Y., \& Respati, N. N. R. (2018). Pengaruh Persepi Negara Asal terhadap Niat Beli Ulang Dimediasi oleh Ekuitas Merek. EJurnal Manajemen Unud, 7(7), 3974-4001.

Robbins, S. P. (2008). Perilaku Organisasi. Jakarta: PT. Indeks.

Saputra, \& Semuel. (2013). Analisa Pengaruh Motivasi, Persepsi, dan Sikap Konsumen Terhadap Keputusan Pembelian Mobil Daihatsu Xenian di Sidoarjo. Jurnal Manajemen Universitas Kristen Petra, 1(1), 1-12. 
Sari, F., \& Pangestuti, E. (2018). Pengaruh EWOM (E-wom) terhadap minat berkunjung dan keputusan berkunjung (Studi Pada Wisata Coban Rais BKPH Pujon). Jurnal Administrasi Bisnis (JAB), 54(1), 1-20.

Setiawan, P. Y., \& Wibawa, I. M. A. (2018). The Effect of EWOM on Intention to Visit and The Mediating Role of Destination Image. IOSR Journal of Business and Management, 20(9), $21-27$.

Shahrinaz, I., Kusuma, J., Yacob, Y., Rahman, A., Abang, D. H., \& Mahdi, A. F. (2016). Relationship and Impact of E $\square$ WOM and Brand Image Towards Purchase Intention of Smartphone. Journal of Scientific Research and Development, 3(5), $117-124$.

Sinay, S. O., \& Hussein, A. S. (2015). Pengaruh EWOM (EWOM ) terhadap sikap dan niat beli konsumen pada produk The Body Shop dalam Forum Female Daity. Jurnal Ilmiah Mahasiswa FEB Universitas Brawijaya, 3(2), 25-34.

Son, J., B., J., \& Bobby, G. (2013). Consumers Purchase Intention Toward Foreign Brands Goods. Management Decision, 51(2), 434-450.

Sugiyono. (2014). Metode Penelitian Bisnis. Bandung: Alfabeta.

Susilawati, H. (2017). Pengaruh EWOM Terhadap Keputusan Berkunjung Di Sindu Kusuma Edupark. Jurnal Khasanah Ilmu, 8(2), 32-38.

Suwarduki, P. R., Yulianto, E., \& Mawardi, M. K. (2016). Pengaruh EWOM Terhadap Citra Destinasi Serta Dampaknya Pada Minat Dan Keputusan Berkunjung (Survei Pada Followers Aktif Akun Instagram Indtravel Yang Telah Mengunjungi Destinasi Wisata Di Indonesia). Jurnal Administrasi Bisnis, 37(2), 1-12.

Syafaruddin, Z., \& Suharyono, S. K. (2016). Pengaruh Komunikasi EWOM terhadap Kepercayaan (Trust) dan Niat Beli (Purchase Intention) serta Dampaknya pada Keputusan (Survey Pada Konsumen Online Shopping Zafertech.Com). Jurnal Bisnis Dan Manajemen, 3(1), 65-72.

Tambunan, A. P. (2007). Menilai Harga Wajar Saham (Stock Valuation). Jakarta: PT. Elex Media.

Themba, G., \& Monica, M. (2013). Brand Related EWOM and Its Effects on Purchase Decisions: An empirical Study of Botswana Students. International Journal of Business Management, 8(8), 31-40.

Tompunu, M. (2014). Analisis Motivasi, Persepsi, Pembelajaran, Dan Sikap Konsumen Pengaruhnya Terhadap Keputusan Pembelian Di KFC Bahu Mall Manado. Jurnal EMBA, 2(3), 610-621.

Toruan, N. N. L., \& Priansa, D. J. (2018). The Influence Of EWOM (E-Wom) Pesona Jawa Baratku On The Decision To Visit Tourists To West Java In 2018. Applied Science, 4(2), 1-12.

Widyanto, A., Sunarti, \& Pangestuti, E. (2017). Pengaruh E-Wom Di Instagram 
Dewa Gede Kresna Mahaputra, Peran Sikap Memediasi...

Terhadap Minat Berkunjung Dan Dampaknya Pada Keputusan Berkunjung (Survei Pada Pengunjung Hawai Waterpark Malang). Jurnal Administrasi Bisnis, 45(1), 94-101.

Wijaya, T., \& Paramita, E. L. (2014). Pengaruh EWOM (EWOM ) Terhadap keputusan PembelianKamera DSLR. Jurnal Manajemen Universitas Tarumanagara, 18(3), 12-19.

Zarrad, H., \& Debab, I. (2015). Analyzing the Effect of EWOM on Tourists' attitude toward Destination and Travel Intention. International Research Journal of Social Sciences, 4(4), 53-60. 